\title{
STUDI ADSORPSI ZAT WARNA NAPHTHOL YELLOW S PADA LIMBAH CAIR MENGGUNAKAN KARBON AKTIF DARI AMPAS TEBU
}

\author{
W. P. Utomo ${ }^{1 *}$, E. Santoso ${ }^{1}$, G. Yuhaneka ${ }^{2}$, A. I. Triantini ${ }^{2}$, M. R. Fatqi ${ }^{2}$, \\ M. F. Huda ${ }^{2}$ dan N. Nurfitria ${ }^{3}$ \\ ${ }^{1}$ Departemen Kimia, Fakultas Ilmu Alam, Institut Teknologi Sepuluh Nopember (ITS), \\ Surabaya 60111, Indonesia \\ ${ }^{2}$ Program Studi Analisis Pengujian Laboratorium SMK Negeri 1 Driyorejo, Gresik 61177, Indonesia \\ ${ }^{3}$ Program Studi Matematika, Fakultas MIPA, Universitas PGRI Ronggolawe, Tuban 62381, Indonesia \\ "e-mail: wp.utomo@chem.its.ac.id
}

\begin{abstract}
ABSTRAK
Penelitian ini bertujuan untuk mendapatkan karbon aktif dari ampas tebu dengan kapasitas adsorpsi yang tinggi terhadap zat warna Naphthol Yellow $S$ serta mengetahui faktor-faktor yang mempengaruhi kapasitas adsorpsi tersebut. Karbon aktif dibuat dari proses pembakaran tidak sempurna ampas tebu yang menghasilkan karbon. Karbon yang dihasilkan diaktivasi dengan $\mathrm{H}_{2} \mathrm{SO}_{4}$ dengan variasi konsentrasi $0,5,1,0,1,5$, dan 2,0 $\mathrm{M}$ dilanjutkan kalsinasi pada suhu $400{ }^{\circ} \mathrm{C}$. Pengukuran luas permukaan karbon aktif dengan metode metilen biru menunjukkan bahwa proses aktivasi berhasil meperluas luas permukaan karbon dari semula $31,87 \mathrm{~m}^{2} / \mathrm{g}$ sebelum aktivasi menjadi $66-72 \mathrm{~m}^{2} / \mathrm{g}$ setelah aktivasi. Karbon aktif dengan konsentrasi $\mathrm{H}_{2} \mathrm{SO}_{4} 2,0 \mathrm{M}$ menunjukkan luas permukaan tertinggi yakni $71,85 \mathrm{~m}^{2} / \mathrm{g}$, namun demikian adsorpsi terbaik ditunjukkan oleh karbon aktif dengan konsentrasi $\mathrm{H}_{2} \mathrm{SO}_{4}$ 0,5 M dengan kapasitas adsorpsi sebesar 83,93\%. Uji adsorpsi menunjukkan bahwa jumlah adsorben terbaik adalah 0,2 gram dengan waktu kontak selama 30 menit. Waktu kontak yang semakin lama ternyata dapat menurunkan jumlah Naphthol Yellow $S$ yang teradsorpsi. Hasil uji adsorpsi terbaik ditunjukkan oleh sampel dengan konsentrasi aktivator $0,5 \mathrm{M}$, massa $0,2 \mathrm{~g}$ dan waktu kontak 30 menit dengan kapasitas adsorpsi $95,81 \%$ atau jumlah zat warna teradsorp sebesar $143,72 \mathrm{mg} / \mathrm{g}$. Studi adsorpsi juga menunjukkan bahwa seluruh proses adsorpsi zat warna Naphtol Yellow $S$ mengikuti model adsorpsi isothemal Langmuir. Pengujian secara kualitatif terhadap limbah batik riil menunjukkan bahwa karbon aktif dapat menurunkan kadar zat warna dalam limbah cair tersebut yag ditandai dengan warna limbah batik yang lebih pudar.
\end{abstract}

Kata kunci: karbon aktif, adsorpsi, limbah batik, Naphthol Yellow S, zat warna

\begin{abstract}
The aim of this research is to get activated carbon from sugarcane bagasse with high adsorption capacity to Naphthol Yellow $S$ and to know factors influencing the adsorption capacity. Activated carbon is prepared by incomplete combustion of sugracane bagasse. The resulting carbon is activated with $\mathrm{H}_{2} \mathrm{SO}_{4}$ with concentration variation of $0.5 ; 1.0 ; 1.5$ and $2.0 \mathrm{M}$ and is continued by calcination at $400{ }^{\circ} \mathrm{C}$. The measurement of the surface area of activated carbon by the methylene blue method indicates that the activation process successfully extends the surface area of carbon from $31.87 \mathrm{~m}^{2} / \mathrm{g}$ before activation to $66-72 \mathrm{~m}^{2} / \mathrm{g}$ after activation. Activated carbon with concentration of $2.0 \mathrm{M} \mathrm{H}_{2} \mathrm{SO}_{4}$ showed the highest surface area of $71.85 \mathrm{~m}^{2} / \mathrm{g}$, however, the best adsorption was shown by activated carbon with a concentration of $0.5 \mathrm{M} \mathrm{H}_{2} \mathrm{SO}_{4}$ with the adsorption capacity of $83.93 \%$. The adsorption test showed that the best amount of adsorbent was $0.2 \mathrm{~g}$ with contact time for 30 minutes. Prolonged contact time can decrease the amount of Naphthol Yellow $S$ adsorbed. The best adsorption test result was shown by sample with activator concentration of $0,5 \mathrm{M}$, mass of $0,2 \mathrm{~g}$ and contact time of 30 min with adsorption capacity $95,81 \%$ or amount of dye adsorbed equal to $143,72 \mathrm{mg} / \mathrm{g}$. The adsorption study also showed that the entire Naphthol Yellow $S$ adsorption process followed the Langmuir isothemal adsorption model. Qualitative testing of real batik waste indicates that activated carbon can reduce the dyes waste containing Naphthol Yellow Sexhibited by the color of batik waste which is more faded.
\end{abstract}

Keywords: activated carbon, adsorption, batik waste, Naphthol Yellow S, dye waste 


\section{PENDAHULUAN}

Batik merupakan salah satu jenis tekstil yang sangat populer di Indonesia. Data dari Kementerian Perindustrian menunjukkan bahwa jumlah unit usaha batik selama 5 tahun sejak 2011 sampai 2015 tumbuh 14,7\% dari 41.623 unit menjadi 47.755 unit usaha. Nilai pembelian bahan baku pun meningkat $12,8 \%$ dari tahun 2011 senilai $\mathrm{Rp} \quad 4,137$ triliun menjadi Rp 4,746 triliun pada tahun 2015 (Pujiastuti, 2015). Meningkatnya jumlah industri batik tentu membawa dampak positif bagi masyarakat Indonesia, khususnya dalam bidang budaya dan ekonomi. Namun, industri batik juga memiliki dampak negatif bagi lingkungan yakni meningkatnya pula jumlah limbah cair yang mengandung zat warna sintetis (Sasongko and Tresna, 2010).

Pada umumnya limbah cair batik mengandung kadar zat organik yang tinggi yang disebabkan oleh sisa-sisa proses pembatikan. Terlepasnya zat warna tersebut ke dalam badan air akan menghalangi penetrasi sinar matahari ke dalam air, mempengaruhi proses fotosintesis pada tumbuhan serta berpengaruh pula pada tatanan suatu ekosistem (Hajati dkk., 2014). Selain itu, zat warna menyebabkan resiko bahaya pada kesehatan manusia antara lain dapat menyebabkan iritasi dan alergi pada kulit, gangguan pada ginjal, hati, otak serta gangguan pada sistem syaraf dan reproduksi (Brookstein, 2009). Bahkan saat ini, zat warna diperkirakan juga bersifat karsinogenik yang dapat menyebabkan kanker (Hazza dan Hussein, 2015). Salah satu jenis zat warna yang banyak digunakan pada industri batik adalah naphtol kuning (Naphthol Yellow S). Pewarna ini dapat memberikan warna yang baik pada kain batik, namun jika tersebar ke lingkungan, naphtol kuning dapat menyebabkan iritasi bahkan memicu kanker kulit pada manusia. Oleh karena itu, kandungan zat warna ini perlu dikurangi dalam limbah batik sebelum limbah dibuang ke badan air (Jain dkk., 2010 dan Yang dkk., 2017)

Beberapa metode telah diterapkan untuk menurunkan kadar zat warna pada limbah zat warna, antara lain melalui proses biodegradasi menggunakan fotokatalis (Natarajan dkk., 2018), bioremediasi menggunakan mikroorganisme tertentu (Ghosh dkk., 2017), ozonisasi (Hu dkk., 2016) maupun adsorpsi menggunakan adsorben (Arifin dkk., 2012; Banerjee dan Chattopadhyaya, 2017; Jain dkk., 2010). Dari berbagai metode yang telah digunakan, metode adsorpsi merupakan metode yang paling banyak digunakan dan potensial dikembangkan lebih lanjut karena prosesnya yang relatif sederhana (Rita, 2012). Namun demikian, penerapan metode adsorpsi tersebut sering terkendala oleh tingginya biaya untuk pembuatan adsorben. Oleh karena itu, adsorben dengan bahan yang murah dan tersedia berlimpah perlu terus dikembangkan.

Salah satu jenis adsorben yang banyak digunakan untuk adsorpsi zat warna adalah karbon aktif (Lempang, 2014). Karbon aktif aktif banyak digunakan sebagai material adsorben karena memiliki porositas dan luas permukaan yang tinggi (Budi dkk., 2016). Sampai saat ini, beberapa penelitiaan telah melaporkan penggunaan berbagai material dasar untuk menyiapkan karbon aktif, antara lain tempurung kelapa (Jamilatun and Setyawan, 2014), sabut kelapa sawit (Puspita dan Firdaus, 2017), sekam padi (Arneli dkk., 2017) dan ampas tebu (Azhar dkk., 2005; Sari dkk., 2017). Meskipun demikian, penggunaan beberapa bahan tersebut terkadang membawa konflik kepentingan karena bahan yang bersangkutan juga sering digunakan untuk pembuatan produk lain. Sebagai contoh tempurung kelapa maupun sabut kelapa sering digunakan untuk produk kerajinan maupun pembuatan arang untuk briket atau bahan bakar. Sementara itu, sekam padi merupakan sumber silika yang tinggi sehingga sering digunakan sebagai bahan untuk sintesis zeolit (Ng dkk., 2015) maupun material aluminosilikat yang lain (Simanjuntak dkk., 2013).

Potensi dihasilkannya ampas tebu di Indonesia cukup besar. Dilihat dari luas area perkebunan tebu, luas perkebunan tebu di Indonesia pada tahun 2015-2017 mencapai sekitar 445-455 ribu hektar. Sementara itu total produksi tebu dalam rentang tahun yang sama berkisar di angka 2,22-2,45 juta ton (Direktorat Jenderal Perkebunan, 2016). Tebu yang diproduksi tersebut umumnya digunakan sebagai bahan baku industri, misalnya dalam industri gula. Menurut Misran. (2005) dalam tiap proses produksi gula di Pabrik Gula (PG), dihasilkan ampas tebu sebesar 32-40\% dari tiap tebu yang diproses. Dalam ampas tebu itu sendiri terkandung komponen antara lain 
monosakarida $(0,5-1,5 \%)$, sukrosa $(11-19 \%)$, zat-zat organik $(0,5-1,5 \%)$, sabut (11-19\%), air $(65-75 \%)$ serta komponen yang lainnya. Kandungan monosakarida, sukrosa, zat organik maupun sabut tersebutlah yang mengandung karbon sehingga dapat digunakan sebagai sumber karbon pada pembuatan karbon aktif (Misran, 2005).

Berdasarkan uraian diatas tampak bahwa ampas tebu merupakan bahan yang berpotensi digunakan sebagai bahan pembuat karbon aktif karena kelimpahannya yang besar dan pemanfaatannya yang belum optimal. Namun demikian, kinerja karbon aktif pada zat warna tertentu misalnya Naphthol Yellow $S$ belum diketahui. Penelitian ini bertujuan untuk mendapatkan karbon aktif dari ampas tebu, serta menggunakan karbon aktif yang telah diperoleh untuk mengadsorpsi limbah buatan berupa larutan zat warna Naphthol Yellow S. Faktor-faktor yang mempengaruhi kemampuan adsorpsi zat warna Naphthol Yellow $S$ oleh karbon aktif dibahas secara detil. Parameter terbaik yang diperoleh selanjutnya digunakan untuk mengadsorpsi limbah riil zat warna yang mengandung Naphthol Yellow $S$.

\section{METODOLOGI}

\section{Bahan}

Bahan-bahan yang digunakan pada penelitian ini adalah ampas tebu yang diperoleh dari daerah Driyorejo, Gresik, $\mathrm{H}_{2} \mathrm{SO}_{4} \quad 98 \%$ (Bratachem), metilen biru, pewarna Naphthol Yellow $S\left(\mathrm{C}_{10} \mathrm{H}_{4} \mathrm{~N}_{2} \mathrm{Na}_{2} \mathrm{O}_{8} \mathrm{~S}\right)$, aquades dan limbah cair zat warna yang berasal dari industri batik di Sidoarjo.

\section{Pembuatan Karbon Aktif dari Ampas Tebu}

Ampas tebu dipotong dengan ukuran 3$5 \mathrm{~cm}$ dan dicuci dengan air. Ampas tebu yang telah bersih selanjutnya dikeringkan di bawah sinar matahari dilanjutkan dalam oven pada suhu $110{ }^{\circ} \mathrm{C}$ selama $1 \mathrm{jam}$. Ampas tebu yang telah kering selanjutnya dibakar dalam wadah tertutup sehingga membatasi pasokan oksigen pada saat proses pembakaran tersebut. Pembatasan oksigen pada proses pembakaran menyebabkan pembakaran tidak sempurna pada ampas tebu yang menghasilkan arang (karbon) (Sudrajat and Pari, 2011). Karbon yang telah diperoleh kemudian ditumbuk halus dengan mortar dan alu, kemudian diayak dengan ayakan 120 mesh. Serbuk karbon yang lolos ayakan 120 mesh (ukuran <120 mesh) selanjutnya siap untuk proses aktivasi.

Proses aktivasi karbon dilakukan menggunakan $\mathrm{H}_{2} \mathrm{SO}_{4}$. Proses aktivasi diawali dengan menyiapkan larutan $\mathrm{H}_{2} \mathrm{SO}_{4} 300 \mathrm{~mL}$ dengan variasi konsentrasi $0,5 \mathrm{M} ; 1 \mathrm{M} ; 1,5 \mathrm{M}$ dan $2 \mathrm{M}$. Pada masing-masing larutan $\mathrm{H}_{2} \mathrm{SO}_{4}$ ditambahkan karbon sebesar 20 gram lalu diaduk menggunakan magnetic stirrer selama 1 jam. Setelah pengadukan, campuran didiamkan selama 48 jam kemudian disaring dan dicuci dengan aquades beberapa kali hingga $\mathrm{pH}$ mendekati netral. Karbon selanjutnya dikeringkan pada suhu $110{ }^{\circ} \mathrm{C}$ selama 1 jam dan sebuk kering selanjutnya dibakar pada suhu $400{ }^{\circ} \mathrm{C}$ selama 2 jam. Proses ini menghasilkan karbon aktif dengan berbagai variasi konsentrasi aktivator. Karbon akttif yang dihasilkan tersebut ditandai dengan kode $\mathrm{C} 0,5 ; \mathrm{C} 1 ; \mathrm{C} 1,5$ dan $\mathrm{C} 2$ untuk masingmasing konsentrasi $\mathrm{H}_{2} \mathrm{SO}_{4} 0,5 \mathrm{M} ; 1 \mathrm{M} ; 1,5 \mathrm{M}$ dan 2 M. Sementara karbon tanpa proses aktivasi ditandai dengan nama $\mathrm{C}$. Karbon aktif $\mathrm{C} 0,5$ selanjutnya dikarakterisasi dengan spektrofotometer infra merah (IR) Shimadzu pada bilangan gelombang 400-4000 $\mathrm{cm}^{-1}$ untuk mengetahui gugus fungsi yang terbentuk setelah proses aktivasi.

\section{Pengukuran Luas Permukaan Karbon}

Pengukuran luas permukaan dilakukan pada ampas tebu yang lolos ayakan 120 mesh (ukuran -120 mesh), karbon tanpa aktivasi dan karbon aktif. Pengukuran dilakukan dengan menggunakan metode adsorpsi metilen biru seperti yang dilakukan oleh Widihati dkk. (2010). Sebelumnya, kurva kalibrasi metilen biru disiapkan terlebih dahulu. Variasi konsentrasi metilen biru yang digunakan untuk pembuatan kurva kalibarasi adalah $1 ; 2 ; 3 ; 4$ dan $5 \mathrm{ppm}(\mathrm{mg} / \mathrm{L})$. Larutan metilen biru diukur absorbansinya pada panjang gelombang $665 \mathrm{~nm}$ menggunakan spektrofotometer UVVis OPTIMA. Absorbansi (y) selanjutnya di plotkan terhadap konsentrasi $(\mathrm{x})$ sehingga diperoleh persamaan regresi $y=a+b x$ dengan $\mathrm{y}$ adalah absorbansi dan $\mathrm{x}$ adalah konsentrasi.

Pada proses adsorpsi metilen biru, sampel ampas tebu (ditandai kode A), karbon tanpa aktivasi $(\mathrm{C} 0)$ dan seluruh karbon aktif hasil aktivasi ( $\mathrm{C} 0,5 ; \mathrm{C} 1 ; \mathrm{C} 1,5$ dan $\mathrm{C} 2)$ ditimbang sebanyak 0,1 gram kemudian masing-masing dimasukkan pada $20 \mathrm{~mL}$ larutan metilen biru100 ppm. Setelah itu 
campuran diaduk dengan magnetic stirrer selama 40 menit. Larutan disaring dan filtrat yang diperoleh diukur absorbansinya menggunakan spektrofotometer UV-Vis OPTIMA. Luas permukaan karbon aktif ditentukan dari jumlah metilen biru yang diadsorpsi, dengan menggunakan Persamaan 1.

$$
S=\frac{\frac{X}{m} \times N \times a}{M}
$$

dimana $\mathrm{S}$ adalah luas permukaan adsorben $\left(\mathrm{m}^{2} / \mathrm{g}\right), \mathrm{x} / \mathrm{m}$ adalah banyaknya metilen biru yang teradsorpsi per gram adsorben $(\mathrm{mg} / \mathrm{g}), \mathrm{N}$ adalah bilangan avogradro $\left(6.02 \times 10^{23}\right.$ partikel/mol), a adalah ukuran 1 molekul adsorbat metilen biru $\left(197 \times 10^{-20}\right)$ dan M adalah berat molekum metilen biru (320,5 $\mathrm{g} / \mathrm{mol}$ ) (Widihati et al., 2012).

\section{Adsorpsi Zat Warna (Variasi Konsentrasi Aktivator, Jumlah Adsorben dan Waktu Kontak)}

Proses adsorpsi zat warna dilakukan dengan menggunakan limbah buatan berupa larutan Naphthol Yellow $S$ (NY) dengan konsentrasi $300 \mathrm{ppm}$ (300 mg/L). Proses adsorpsi ini dilakukan dengan metode batch dengan berbagai variasi secara berurutan, dimana pertama dilakukan adsorpsi NY dengan variasi konsentrasi aktivator (dengan sampel yang berbeda-beda yakni A; C0; C0,5; $\mathrm{C} 1 ; \mathrm{C} 1,5$ dan $\mathrm{C} 2$ ). Adsorben dengan kapasitas adsorpsi tertinggi digunakan untuk tahap adsorpsi dengan variasi jumlah adsorben. Jumlah adsorben terbaik selanjutnya digunakan pada proses adsorpesi dengan waktu kontak.

Pada proses adsorpsi variasi konsentrasi aktivator, sampel adsorben $(\mathrm{A} ; \mathrm{C} 0 ; \mathrm{C} 0,5 ; \mathrm{C} 1$; $\mathrm{C} 1,5$ dan $\mathrm{C} 2$ ) ditimbang sebanyak 0,1 gram. Adsorben selanjutnya ditambahkan ke dalam $50 \mathrm{ml}$ larutan NY 300 ppm dan diaduk dengan magnetic stirrer selama 40 menit. Campuran kemudian disaring dan filtratnya dianalisis menggunakan spektrofotometer UV-Vis pada panjang gelombang $480 \mathrm{~nm}$. Dengan prinsip dan cara kerja yang sama dilakukan adsorpsi NY dengan variasi jumlah $(0,05 ; 0,1 ; 0,2 ; 0,3$ dan 0,4 gram) serta variasi waktu kontak (15, 30, 40, 60 dan 90 menit). Jumlah NY yang teradsorpsi oleh adsorben $\left(\mathrm{q}_{\mathrm{e}}\right)$ dihitung berdasarkan Persamaan 2, sementara itu kapasitas adsorpsi dihitung berdasarkan Persamaan 3.

$$
\begin{gathered}
q_{e}=\frac{\left(C_{0}-C_{e}\right) \times V}{M} \\
\begin{array}{r}
\text { Kapasitas adsorpsi }(\%) \\
=\frac{\left(C_{0}-C_{e}\right)}{C_{0}} \times 100 \%
\end{array}
\end{gathered}
$$

dimana $\mathrm{q}_{\mathrm{e}}$ ada jumlah $\mathrm{NY}$ teradsorpsi oleh tiap gram adsorben $(\mathrm{mg} / \mathrm{g}), \mathrm{C}_{0}$ adalah konsentrasi awal NY (mg/L), $\mathrm{C}_{\mathrm{e}}$ adalah konsentrasi kesetimbangan $\mathrm{NY}(\mathrm{mg} / \mathrm{L}), \mathrm{V}$ adalah volume larutan (L), $\mathrm{M}$ adalah massa adsorben $(\mathrm{g})$ (Tongpoothorn dkk., 2011). Sampel C0,5 yang telah digunakan untuk proses selanjutnya dikarakterisasi dengan spektrofotometer infra merah (IR) Shimadzu pada bilangan gelombang 400-4000 $\mathrm{cm}^{-1}$ untuk mengetahui adanya perubahan yang terjadi pada gugus fungsi karbon setelah proses adsorpsi.

\section{Penentuan Model Adsorpsi Isotermal NY pada Karbon Aktif}

Penentuan model adsorpsi isotermal dilakukan dengan menerapkan regresi linear pada persamaan isotermal Langmuir (Persamaan 4) dan persamaan Freundlich (Persamaan 5). Pada persamaan tersebut, $\mathrm{q}_{\mathrm{e}}$ adalah jumlah NY teradsorpsi oleh tiap gram adsorben $(\mathrm{mg} / \mathrm{g}), \quad \mathrm{C}_{\mathrm{e}}$ adalah konsentrasi kesetimbangan $\mathrm{NY} \quad(\mathrm{mg} / \mathrm{L}), \quad \mathrm{K}_{\mathrm{f}}$ adalah kapasitas adsorpsi relatif adsorben (mg/g), 1/n adalah konstanta indikatif yang menunjukkan intensitas proses adsorpsi, $\mathrm{Q}_{0}$ adalah kapasitas adsorpsi lapisan tunggal $(\mathrm{mg} / \mathrm{g})$, dan $\mathrm{b}$ adalah konstanta energi adsorpsi. Persamaan regresi linear untuk persamaan Langmuir dibuat dengan memplotkan Ce/qe (sebagai sumbu y) terhadap Ce (sebagai sumbu x). Sementara itu, persamaan regresi linear untuk persamaan Freundlich dibuat dengan memplotkan $\log \mathrm{q}_{\mathrm{e}}$ (sebagai sumbu y) terhadap $\log \mathrm{C}_{\mathrm{e}}$ (sebagai sumbu $\mathrm{x}$ ). Nilai koefisien korelasi (r) dari kedua persamaan regresi linear kemudian dibandingkan, dimana nilai $r$ yang lebih mendekati 1 merupakan model adsorpsi 
isotermal yang lebih sesuai (Estiaty, 2012; Utomo dkk., 2018).

$$
\begin{gathered}
\log q_{e}=\log K_{f}+\frac{1}{n} \log C_{e} \\
\frac{C_{e}}{q_{e}}=\frac{1}{Q_{0} b}+\frac{C_{e}}{Q_{0}}
\end{gathered}
$$

\begin{abstract}
Adsorbsi Limbah Riil dengan Karbon Aktif Uji adsorpsi limbah riil industri batik dilakukan secara kualitatif dengan melihat perubahan tingkat kejernihan sebelum dan sesudah proses adsorpsi dengan karbon aktif. Parameter optimal yang telah diperoleh dari prosedur penentuan konsentrasi aktivator, jumlah adsorben dan waktu kontak selanjutnya digunakan untuk adsorpsi limbah riil. Karbon aktif dengan jumlah tertentu ditambahkan dalam limbah riil dan diaduk dalam selang waktu tertentu. Campuran disaring dan filtratnya dibandingkan secara visual dengan limbah riil.
\end{abstract}

\section{HASIL DAN PEMBAHASAN}

\section{Pengaruh Konsentrasi Asam Sulfat $\left(\mathrm{H}_{2} \mathrm{SO}_{4}\right)$ terhadap Karakteristik Permukaan Karbon Aktif}

Karbon aktif ampas tebu dihasilkan dari ampas tebu yang dibakar menjadi arang (karbon), kemudian dilakukan aktivasi secara kimia dengan merendam karbon tersbut menggunakan larutan asam seperti $\mathrm{H}_{2} \mathrm{SO}_{4}$. Karbon dihasilkan dari pembakaran yang tidak sempurna, dimana dilakukan pembatasan pada jumlah oksigen pada saat proses pembakaran tersebut sehingga ampas tebu yang terbakar tidak sepenuhnya teroksidasi sempurna menjadi $\mathrm{CO}_{2}$ dan $\mathrm{H}_{2} \mathrm{O}$, melainkan membentuk karbon. Proses ini, yang secara umum juga dikenal dengan karbonisasi, merupakan metode yang sederhana dan murah sehingga lebih mudah diterapkan dalam pembuatan karbon aktif skala besar (Lempang, 2014). Sebelum ampas tebu dikarbonisasi, ampas tebu terlebih dahulu dijemur dibawah sinar matahari dan dioven dengan suhu $110{ }^{\circ} \mathrm{C}$ selama 1 jam untuk memastikan ampas tebu kering sebelum dibakar.

Karbon yang diperoleh selanjutnya ditumbuk hingga halus dan diayak untuk menyeragamkan ukuran partikelnya menggunakan ayakan 120 mesh. Karbon aktif yang lolos ayakan 120 mesh (ukuran <120 mesh) yag sleanjutnya digunakan. Proses aktivasi dilakukan dengan menggunakan asam sulfat dengan variasi konsentrasi dari 0,5; 1,0;1,5 dan 2,0 $\mathrm{M}$ dilanjutkan dengan kalsinasi pada suhu $400{ }^{\circ} \mathrm{C}$. Contoh karbon aktif dari ampas tebu yang dihasilkan ditunjukkan pada Gambar 1. Pada saat proses aktivasi, terjadi proses yang dapat meningkatkan luas permukaan karbon. Budi et al (2015) melaporkan bahwa terdapat tiga proses selama aktivasi, yakni terbukanya pori-pori yang sebelumnya tertutup, pembentukan pori-pori baru dan perluasan pori-pori yang telah ada. Agen aktivator yang masuk ke dalam struktur karbon akan membentuk pori-pori kecil sehingga memperluas luas permukaan (Budi et al., 2016). Terjadinya peningkatan luas permukaan karbon ini ditunjukkan dari hasil pengukuran luas permukaan dengan metode metilen biru sebagaimana ditampilkan pada Gambar 2.

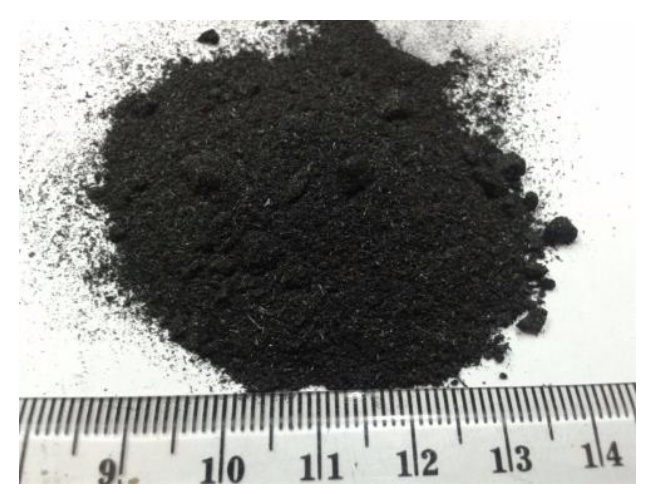

Gambar 1. Karbon aktif dari ampas tebu dengan konsentrasi aktivator $\left(\mathrm{H}_{2} \mathrm{SO}_{4}\right) 0,5 \mathrm{M}$

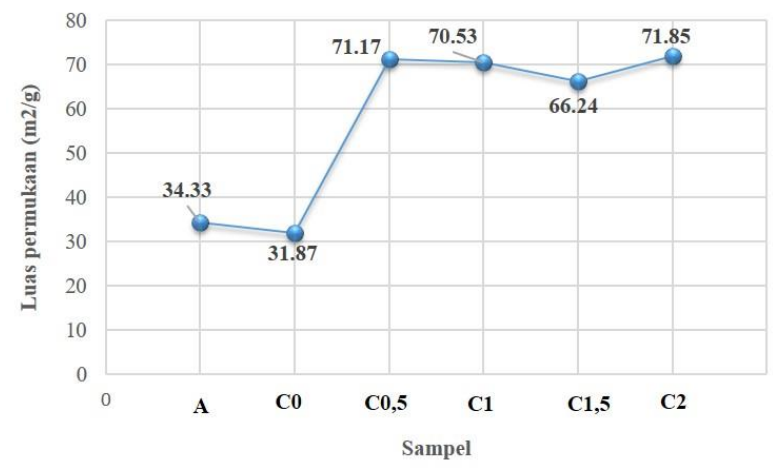

Gambar 2. Luas permukaan ampas tebu (A), karbon tanpa aktivasi (C0) dan karbon aktif (C0,5; C1, C1,5 dan C2) yang diukur dengan metode metilen biru. Ukuran seluruh sampel adalah 120 mesh. 
Studi Adsorpsi Zat Warna Naphthol Yellow S Pada Limbah Cair Menggunakan Karbon Aktif dari Ampas Tebu Wahyu Prasetyo Utomo, Eko Santoso, Grace Yuhaneka², Aprilia Isti Triantini, Moh. Rizkhulloh Fatqi,

Muchammad Fatkur Huda, Nia Nurfitria

Data pada Gambar 2 menunjukkan bahwa proses aktivasi telah berhasil meningkatkan luas permukaan karbon hingga dua kali lipat, yakni dari semula $\pm 31-34$ $\mathrm{m}^{2}$ /gram sebelum aktivasi (pada ampas dan karbon tanpa aktivasi) menjadi \pm 66-72 $\mathrm{m}^{2} /$ gram setelah proses aktivasi. Perbedaan konsentrasi aktivator juga berpengaruh pada luas area yang dihasilkan. Secara umum, semakin tinggi konsentrasi asam sulfat, semakin tinggi pula luas permukaan karbon aktif yang terbentuk dimana luas permukaan tertinggi ditunjukkan oleh konsentrasi asam sulfat $2 \mathrm{M}$ dengan luas $71,85 \mathrm{~m}^{2} /$ gram (Budi dkk., 2016).
Selain meningkatkan luas permukaan karbon, proses aktivasi dengan asam juga memungkinkan terbentuknya gugus-gugus aktif pada struktur karbon aktif yang dapat berikatan dengan adsorbat sehingga meningkatkan kemampuan adsorpsinya. Arnelli dkk. (2017) menjelaskan proses aktivasi dengan asam menyebabkan terbentuknya gugus fungsi tertentu pada karbon aktif, misalnya gugus keton, alkohol, asam dan aldehid (Arneli dkk., 2017). Oleh karena itu, untuk mengetahui gugus fungsi yang mungkin terbentuk pada saat proses aktivasi ini, dilakukan karakterisasi IR dimana hasilnya ditunjukkan pada Gambar 3.

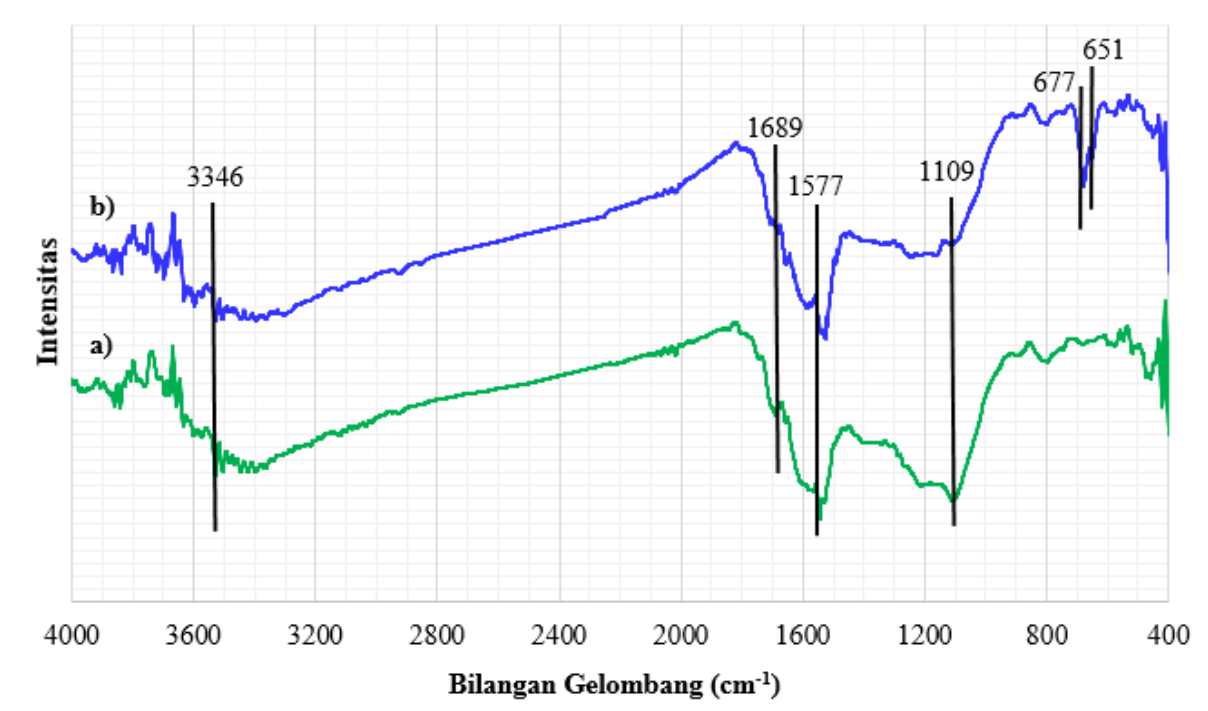

Gambar 3. Spektra IR karbon aktif C0,5 a) sebelum dan b) sesudah adsorpsi

Spektrum IR karbon $\mathrm{C} 0,5$ sebelum proses adsorpsi menunjukkan adanya beberapa puncak serapan IR yakni puncak yang melebar pada bilangan gelombang antara 3200-3700 $\mathrm{cm}^{-1}$ yang merupakan puncak vibrasi $\mathrm{O}-\mathrm{H}$, $1689 \mathrm{~cm}^{-1}$ yang merupakan puncak vibrasi $\mathrm{C}=\mathrm{O}$ karbonil, $1109 \mathrm{~cm}^{-1}$ dari vibrasi stretching C-O dari grup asam, alkohol, fenol eter ataupun ester (Alves dkk., 2013). Sementara itu, Rios dkk. menjelaskan bahwa puncak serapan di sekitar bilangan gelombang $1500 \mathrm{~cm}^{-1}\left(1577 \mathrm{~cm}^{-1}\right)$ mengindikasikan keberadaan gugus $\mathrm{COO}^{-}$(Rios dkk., 2003). Berdasarkan laporan tersebut, keberadaan puncak gugus $\mathrm{C}=\mathrm{O}$ karbonil, $\mathrm{C}-\mathrm{O}, \mathrm{O}-\mathrm{H}$ (hidroksil) dan $\mathrm{COO}^{-}$menunjukkan keberadaan gugus asam karboksilat (Boehm, 1966; Rios dkk., 2003).
Hasil karakterisasi dengan IR tersebut menunjukkan bahwa karbon aktif memiliki gugus-gugus fungsi yang dapat berperan sebagai sisi aktif di permukaannya yang dapat menjadi situs terjadinya interaksi dengan molekul zat warna, baik melalui interaksi kimia melalui pembentukan ikatan kimia maupun melalui pembentukan ikatan fisik. Proses aktivasi dengan asam ternyata tidak hanya membentuk luas permukaan yang lebih besar namun juga menghasilkan gugus-gugus fungsi di permukaan karbon tersebut dkk., 2009; Rios dkk., 2003). 


\section{Pengaruh Konsentrasi Aktivator pada Kemampuan Adsorpsi Karbon Aktif}

Aktivasi karbon aktif dengan berbagai konsentrasi aktivator menunjukkan bahwa terjadi peningkatan luas permukaan karbon aktif dan pembentukan gugus fungsi pada permukaanya. Karbon aktif yang telah dibuat tersebut, beserta karbon sebelum aktivasi dan ampas tebu digunakan untuk proses adsorpsi zat warna NY sebagai limbah buatan.
Kemampuan adsorpsi karbon aktif pada NY ditunjukkan pada Gambar 4. Besarnya kapasitas adsorpsi (dalam \%) menunjukkan banyaknya NK yang diserap oleh karbon aktif dalam larutan tersebut. Sebagai contoh kapasitas adsorpsi $\mathrm{C} 0$ adalah $79,40 \%$, artinya sebanyak $79,40 \%$ NK berhasil dihilangkan dari cairan limbah buatan, atau sebanyak $11,9103 \mathrm{mg}$ dari total $15 \mathrm{mg} \mathrm{NK}$ berhasil dihilangkan dari limbah buatan.

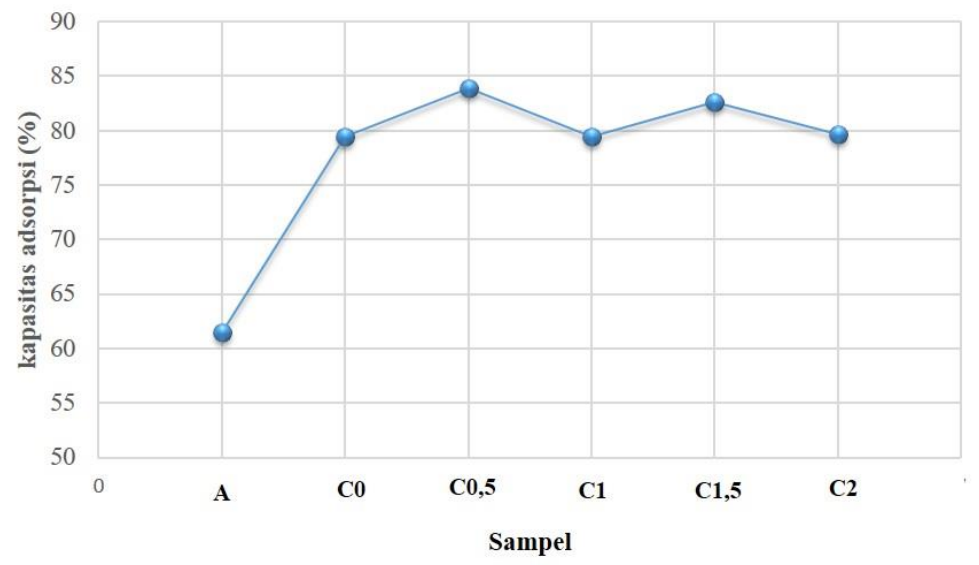

Gambar 4. Kapasitas adsorpsi karbon aktif dengan berbagai konsentrasi asam sulfat

Hasil yang diperoleh menunjukkan bahwa kapasitas karbon $\mathrm{C} 0,5$ memiliki kapasitas adsorpsi tertinggi yakni mencapai 83,93\%. Namun demikian, terdapat kecendurungan dimana kapasitas adsorpsi baik sebelum proses aktivasi dan setelah proses aktivasi menunjukkan nilai tidak terlalu berbeda, yakni $79,40 \%$ pada C0 dan antara $79,44-83,93 \%$ pada karbon setelah aktivasi. Sementara itu, kapasitas adsorpsi ampas tebu jauh lebih rendah berkisar $61,50 \%$. Hal ini mengindikasikan bahwa proses adsorpsi zat warna NY tidak serta merta dipengaruhi oleh luas permukaannya atau gugus fungsinya saja, seperti gugus $\mathrm{O}-\mathrm{H}$ (hidroksil) maupun $\mathrm{COO}^{-}$ (gugus asam karboksilat) yang dapat berperan sebagai sisi aktif (Boehm, 1966; Rios dkk., 2003; Sari dkk., 2017), namun merupakan perpaduan keduanya. Sementara itu, karbon sebelum aktivasi menunjukkan nilai yang tidak terlalu berbeda dengan karbon aktif, padahal luas permukaan karbon sebelum aktivasi jauh lebih rendah dibandingkan karbon aktif. Hal ini menunjukkan bahwa peningkatan luas permukaan tidak serta merta menjadi faktor penentu proses adsorpsi. Pori yang terbentuk pada saat proses aktivasi diperkirakan terlalu kecil ukurannya untuk menjadi situs adsorpsi bagi NY sehingga NY tidak teradsorpsi ke dalam pori tersebut walaupun pori memiliki situs/gugus aktif untuk berikatan. Selain itu, gugus aktif pada karbon aktif yang diperkirakan dapat menjadi situs untuk membentuk ikatan dengan zat warna merupakan gugus karboksilat yang lebih cocok digunakan pada jenis zat warna kationik (Azhar et al., 2005; Goswami and Phukan, 2017).

\section{Model Adsorpsi Isotermal NY dengan Adsorben}

Penentuan model adsorpsi isotermal dilakukan untuk mengetahui jenis adsorpsi yang terjadi dan kemungkinan ikatan yang terbentuk sehingga dapat memberikan petunjuk faktor yang berpengaruh pada adsorpsi NY oleh adsorben. Pemodelan tersebut dilakukan dengan membuat regresi linear dari persamaan Langmuir dan persamaan Freundlich. Pada proses tersebut, 
dapat diperoleh juga koefisien korelasi (R) yang menunjukkan ada tidaknya korelasi dan tingkat korelasi antara data pada sumbu $\mathrm{x}$ dengan sumbu $\mathrm{y}$, dimana nilai $\mathrm{R}$ yang mendekati 1 merupakan data yang memiliki korelasi lebih tinggi. Korelasi tertinggi diperoleh jika $\mathrm{R}=1$ (Estiaty, 2012; Miller dan Miller, 2010). Pada penelitian ini, persamaan garis lurus yang dihasilkan dari persamaan Langmuir adalah $\mathrm{y}=0,00132 \mathrm{x}-0,2788$ $(\mathrm{R}=0,9984)$ dan persamaan Freundlich adalah $y=-0,2703 x+1,9944 \quad(R=0,9950) . \quad$ Koefisien korelasi (R) pada plot persamaan Langmuir lebih tinggi daripada koefisien korelasi pada persamaan Freundlich yang mengindikasikan bahwa proses adsorpsi NY mengikuti model adsorpsi isothermal Langmuir.

Model adsorpsi isotermal ini mengasumsikan bahwa adsorpsi yang terjadi lebih dipengaruhi oleh interaksi kimia, sehingga diperkirkan adsorspsi NY oleh karbon aktif terbentuk akibat terjadinya ikatan kimia antara NY dengan gugus karboksilat yang terdapat pada permukaan karbon aktif. Alves dkk. menggambarkan bahwa ikatan yang terbentuk antara zat warna dengan gugus asam karboksilat ini dapat berupa pembentukan ikatan hidrogen antara atom oksigen (O) pada asam karboksilat dengan hidrogen $(\mathrm{H})$ dari zat warna, maupun hidrogen $(\mathrm{H})$ dari gugus asam karboksilat dengan oksigen $(\mathrm{O})$ maupun atom elektronegatif lain (misalnya nitrogen $(\mathrm{N})$ ) dari zat warna (Alves et al., 2013). Struktur NY ditampilkan pada Gambar 5. Berdasarkan strukturnya, NY merupakan zat warna anionik yang akan membentuk anion jika dilarutkan dalam air dengan melepaskan $\mathrm{Na}^{+}$. Pada struktur NY, tampak adanya atom-atom oksigen $(\mathrm{O})$ yang dapat membentuk ikatan hidrogen (Jain dkk., 2010). Berdasarkan hasil tersebut, interaksi yang terjadi antara NY dengan karbon aktif diperkirakan terjadi akibat adanya ikatan hidrogen antara atom-atom oksigen $(\mathrm{O})$ yang terdapat pada NY dengan atom hidrogen $(\mathrm{H})$ pada gugus asam karboksilat karbon aktif. Jika atom $\mathrm{H}$ pada gugus asam karboksilat tersebut berada pada pori yang berukuran lebih kecil daripada ukuran molekul NY, maka NY tidak dapat teradsorp oleh karbon aktif.<smiles>NS(=O)(=O)c1ccc2c([N+](=O)[O-])cc([N+](=O)[O-])c(O)c2c1</smiles>

Gambar 5. Struktur Naphthol Yellow S

\section{Pengaruh Jumlah dan Waktu Kontak pada Kemampuan Adsorpsi Karbon Aktif}

Karbon aktif dengan kapasitas adsorpsi tertinggi $(\mathrm{C} 0,5)$ dipilih untuk proses adsorpsi dengan variasi jumlah adsorben. Variasi jumlah adsorben ini penting untuk perkiraan penerapan karbon aktif pada pengolahan limbah skala besar. Jumlah karbon aktif yang minimal, dengan kapasitas adsorpsi yang tinggi merupakan parameter yang diharapkan sehingga tidak membutuhkan biaya produksi adsorben yang besar. Pada pengaruh jumlah adsorben, dilakukan variasi jumlah karbon aktif yang ditambahkan pada limbah dan data adsorpsi yang diperoleh ditunjukkan pada Gambar 6. Data pada Gambar 6 menunjukkan bahwa kapasitas adsorpsi meninggkat seiring dengan meningkatnya massa adsorben sampai 0,2 gram. Jumlah karbon aktif 0,2 gram memiliki kapasitas adsorpsi terbesar dibandingkan yang lainnya, yakni 93,55\% atau tiap gram karbon aktif dapat menyerap 140,32 mg NY. Nilai ini meningkat 9,62\% dari massa 0,1 gram. Hasil ini sesuai dengan penelitian yang dilaporkan oleh Arifin dkk. yang menyatakan bahwa kapasitas adsorpsi semakin meningkat dengan meningkatnya jumlah adsorben (Arifin dkk., 2012). Namun demikian, kapasitas adsorpsi ini cenderung mengalami penurunan pada massa adsorben 0,3 dan 0,4 gram yang diperkirakan sebagai akibat dari intensitas tumbukan yang semakin tinggi antara adsorben, molekul NY dan airakibat jumlah adsorben yang bertambah sehingga memungkinkan terlepasnya kembali NY yang telah teradsorpsi oleh adsorben (Sari dkk., 2017). 


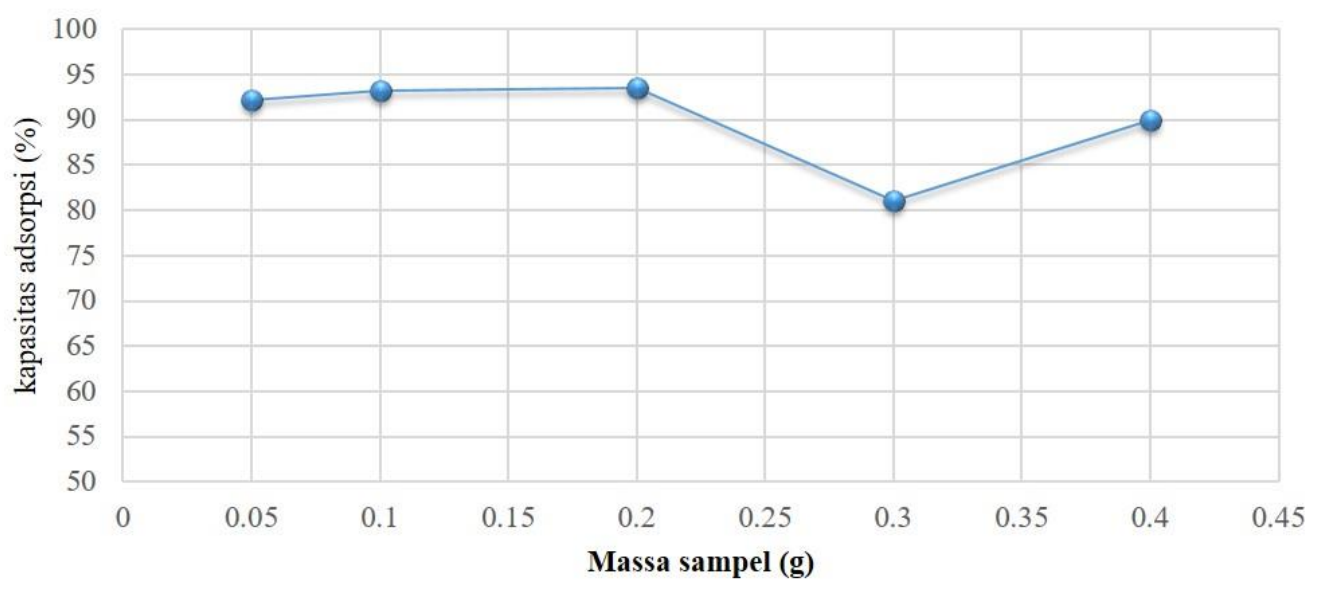

Gambar 6. Kapasitas adsorpsi karbon aktif pada berbagai variasi massa adsorben

Waktu kontak juga berpengaruh pada kemampuan adsorpsi karbon aktif. Pengukuran kapasitas adsorpsi karbon aktif dengan pengaruh waktu kontak dilakukan menggunakan karbon aktif $\mathrm{C} 0,5$ dengan jumlah adsorben 0,2 gram. Data kemampuan adsorpsi C0,5 dengan berbagai variasi waktu kontak ditunjukkan pada Gambar 7. Data pada gambar tersebut menunjukkan bahwa waktu kontak 30 menit menunjukkan kapasitas adsorpsi tertinggi sebesar $95,82 \%$ diikuti oleh waktu 90 menit sebesar 92,99\%. Dengan kapasitas tersebut sebesar $95,81 \%$ tersebut, adsorben C0 dapat mengadsorpsi sebanyak $143,72 \mathrm{mg} / \mathrm{g}$ NY dari limbah buatan.

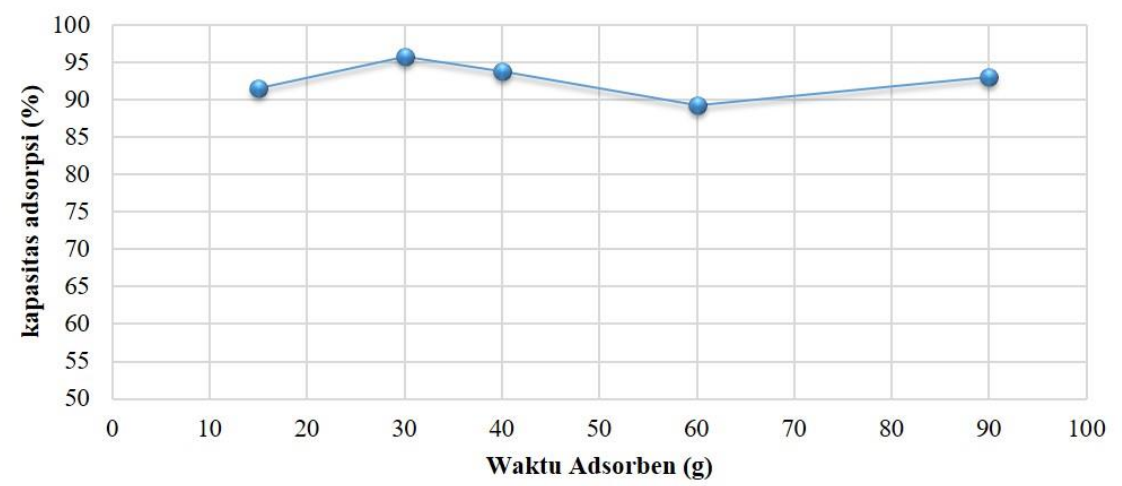

Gambar 7. Kapasitas adsorpsi karbon aktif pada berbagai variasi waktu kontak

Secara umum, data kapasitas adosorpsi pada berbagai variasi waktu ini menunjukkan nilai yang tinggi, yakni diatas 89\% sejak dari awal proses adsorpsi. Penelitian-penelitian sebelumnya melaporkan bahwa pada proses adsorpsi, terjadi peningkatan kapasitas adsorpsi seiring dengan berjalannya waktu, dan mencapai kesetimbangan pada waktu tertentu. Arifin dkk. melakukan adsorpsi zat warna direct black $\mathrm{T}$ dengan kitosan dan mendapatkan waktu optimum (kesetimbangan) diperoleh setelah 360 menit dengan besar penurunan zat warna $45-55 \%$ (Arifin dkk., 2012). Sementara itu, Sari dkk. melakukan adsorpsi zat warna Precion merah dengan karbon aktif dari ampas tebu dan mendapatkan waktu optimum pada 90 menit dengan kapasitas adsorpsi adsorben sebesar 6,9 mg/g (Sari et al., 2017). Hasil pada penelitian ini menunjukkan bahwa kapasitas adsorpsi karbon aktif dari ampas tebu dalam penelitian ini memiliki kamampuan yang tinggi dalam mengadsorpsi zat warna NY. Nilai kapasitas adsorpsi yang mencapai diatas $89 \%$ dari menit ke-15 ini menunjukkan bahwa proses adsorpsi dapat berjalan dengan cepat sehingga waktu pada 30 menit dipilih sebagai waktu yang optimal untuk proses adsorpsi. 
Karbon aktif C0,5 yang telah digunakan dalam proses adsorpsi selanjutnya dikarakterisasi dengan IR untuk mengetahui perubahan gugus yang mungkin terjadi setelah proses adsorprsi. Hal ini disebabkan karena proses adsorpsi mengikuti model Langmuir dimana interaksi yang terjadi antara karbon aktif dan NY merupakan interaksi kimia sehingga diharapkan interaksi tersebut dapat terdeteksi melalui IR. Hasil spektra IR dari sampel C0,5 setelah adsorpsi dan perbandinggannya dengan spektra sebelum adsoprsi ditunjukkan pada Gambar 3. Secara umum, tidak terjadi perubahan yang berbarti pada spektra IR C0,5 setalah proses adsorpsi. Perbedaan tampak pada intensitas puncak yang lebih besar pada bilangan gelombang 677 dan $651 \mathrm{~cm}^{-1}$. Puncak serapan tersebut berasal dari puncak out of plane (OOP) senyawa aromatis (Pavia dkk., 2001). Peningkatan intensitas puncak OOP aromatis tersebut mengindikasikan bahwa terdapat peningkatan struktur aromatis pada karbon aktif yang diperkirakan berasal dari molekul NY yang tersadsorpsi di permukaan karbon aktif. Hasil ini mengkonfirmasi terjadinya adsorpsi NY di permukaan karbon aktif.

\section{Kemampuan Adsorbsi Karbon Aktif Terhadap Limbah Riil}

Parameter terbaik telah diperoleh untuk proses adsorpsi limbah adalah sampel $\mathrm{C} 0,5$, massa adsorben 0,2 gram dan waktu kontak 30 menit. Parameter ini digunakan untuk adsorpsi pada limbah riil. Uji adosorpsi pada limbah riil dilakukan secara kualitatif dengan melihat berbedaan warna pada limbah sebelum dan sesudah adsorspi secara visual. Pengamatan secara kualitatif ini dilakukan karena limbah riil diperkirakan mengandung senyawasenyawa lain sehingga lebih kompleks yang ditandai dengan warna limbah yang jauh lebih pekat dan tidak lagi berwarna kuning. Hasil adsorpsi terhadap limbah buatan NY menunjukkan perbedaan yang signifikan sebagaimana ditampilkan pada Gambar 8. Hal tersebut juga terjadi pada limbah riil, namun tidak sebesar pada limbah buatan. Percobaan dengan meningkatkan jumlah adsorben menjdi 2,3 gram menunjukkan bahwa penurunan warna limbah menjadi lebih pudar.Hasil yang diperoleh menunjukkan bahwa karbon aktif C0 berpotensi digunakan untuk adsorben pada pengolahan limbah batik yang mengandung NY. Namun demikian, perlu perlakuan awal pada sampel riil sebelum adsorpsi NY dengan karbbon aktif untuk mengurangi matriks pengganggu pada saat proses adsorpsi. Keberadaan matriks pengganggu (kandungan senyawa lain) dalam limbah zat warna dapat menyebabkan proses adsorpsi menjadi lebih kompleks (Zhu dkk., 2016).

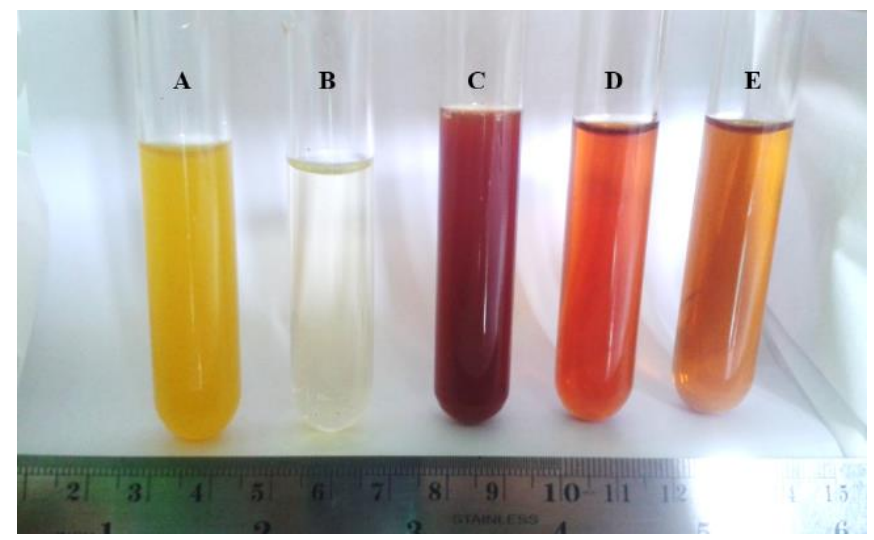

Gambar 8 Hasil uji adsorpsi limbah buatan dan limbah asli dengan 0,2 gram C0,5 dan waktu 30 menit pada a) limbah buatan NY 300 ppm, b) limbah buatan setelah adsorpsi, c) limbah riil sebelum adsorpsi, d) limbah riilsetelah adsorpsi dengan 0,2 g adsorben dan e) limbah riilsetelah adsorpsi dengan $2,3 \mathrm{~g}$ adsorben 


\section{KESIMPULAN}

Karbon aktif dengan kapasitas adsorpsi yang tinggi berhasil dibuat dari ampas tebu. Proses aktivasi ampas tebu dengan asam sulfat berhasil meningkatkan luas permukaan karbon aktif hingga dua kali luas permukaan karbon tanpa aktivasi. Namun demikian, luas permukaan karbon aktif tersebut tidak terlalu memberikan pengaruh pada kapasitas adsorpsi karbon aktif. Mekanismee adsorpsi karbon aktif mengikuti model adsorpsi isotermal Langmuir dimana interaksi yang terjadi merupakan interaksi kimia antara NY dengan karbon aktif. Konsentrasi aktivator terbaik ditunjukkan pada konsentrasi asam sulfat 0,5 M, jumlah adsorben 0,2 gram dan waktu optimal adsorpsi dicapai pada 30 menit. Hasil penelitian ini menunjukkan bahwa karbon aktif dari ampas tebu berpotensi digunakan untuk adsorben pada limbah industri batik yang mengandung Naphthol Yellow S.

\section{DAFTAR PUSTAKA}

Alves, C.C.O., Franca, A.S., Oliveira, L.S., 2013. Evaluation of an Adsorbent Based on Agricultural Waste (Corn Cobs) for Removal of Tyrosine and Phenylalanine from Aqueous Solutions [WWW Document]. BioMed Res. Int. https://doi.org/10.1155/2013/978256

Arifin, Z., Irawan, D., Rahim, M., Ramantiya, F., 2012. Adsorpsi Zat Warna Direct Black 38 Menggunakan Kitosan Berbasis Limbah Udang Delta Mahakam. Sains Dan Terap. Kim. 6, 35-45.

Arneli, Safitri, Z.F., Pangestika, A.W., Fauziah, F., Wahyuningrum, V.N., Astuti, Y., 2017. The influence of activating agents on the performance of rice husk-based carbon for sodium lauryl sulfate and chrome $(\mathrm{Cr})$ metal adsorptions. IOP Conf. Ser. Mater. Sci. Eng. 172, 012007. https://doi.org/10.1088/1757899X/172/1/012007

Azhar, S.S., Liew, A.G., Suhardy, D., Hafiz, K.F., Hatim, M.. I., 2005. Dye Removal from Aqueous Solution by using Adsorption on Treated Sugarcane Bagasse. Am. J. Appl. Sci.
2 ,

$1499-1503$.

https://doi.org/10.3844/ajassp.2005.14 99.1503

Banerjee, S., Chattopadhyaya, M.C., 2017. Adsorption characteristics for the removal of a toxic dye, tartrazine from aqueous solutions by a low cost agricultural by-product. Arab. J. Chem. 10, S1629-S1638. https://doi.org/10.1016/j.arabjc.2013.0 6.005

Boehm, H.P., 1966. Chemical Identification of Surface Groups, in: Eley, D.D., Pines, H., Weisz, P.B. (Eds.), Advances in Catalysis. Academic Press, pp. 179274. https://doi.org/10.1016/S03600564(08)60354-5

Brookstein, D.S., 2009. Factors Associated with Textile Pattern Dermatitis Caused by Contact Allergy to Dyes, Finishes, Foams, and Preservatives. Dermatol. Clin., Contact Dermatitis 27 , 309-322. https://doi.org/10.1016/j.det.2009.05.0 01

Budi, E., Umiatin, Nasbey, H., Bintoro, R.A., Wulandari, F., Erlina, 2016. Activated coconut shell charcoal carbon using chemical-physical activation. p. 050003. https://doi.org/10.1063/1.4941886

Cheong, K.E., 2012. Removal of Basic Dyes Using Sugarcane Bagasse (Thesis). Faculty of Engineering and Science, University Tuanku Abdul Rahman, Malaysia.

Direktorat Jenderal Perkebunan, 2016. Statistik Perkebunan Indonesia Komoditas Tebu 2015-2017. Kementerian Pertanian.

Estiaty, L.M., 2012. Kesetimbangan Dan Kinetika Adsorpsi Ion C2+ pada Zeolit-H. J. Ris. Geol. Dan Pertamb. 22, 115. https://doi.org/10.14203/risetgeotam2 012.v22.63

Ghosh, A., Dastidar, M.G., Sreekrishnan, T.R., 2017. Bioremediation of chromium complex dyes and treatment of sludge generated during the process. Int. Biodeterior. Biodegrad., Environmental Biotechnologies for Sustainable Development (EBSuD) 119 , 448-460. 
Studi Adsorpsi Zat Warna Naphthol Yellow S Pada Limbah Cair Menggunakan Karbon Aktif dari Ampas Tebu Wahyu Prasetyo Utomo, Eko Santoso, Grace Yuhaneka², Aprilia Isti Triantini, Moh. Rizkhulloh Fatqi,

Muchammad Fatkur Huda, Nia Nurfitria

https://doi.org/10.1016/j.ibiod.2016.08 .013

Goswami, M., Phukan, P., 2017. Enhanced adsorption of cationic dyes using sulfonic acid modified activated carbon. J. Environ. Chem. Eng. 5, 3508-3517.

https://doi.org/10.1016/j.jece.2017.07. 016

Hajati, S., Ghaedi, M., Karimi, F., Barazesh, B., Sahraei, R., Daneshfar, A., 2014. Competitive adsorption of Direct Yellow 12 and Reactive Orange 12 on ZnS:Mn nanoparticles loaded on activated carbon as novel adsorbent. J. Ind. Eng. Chem. 20, 564-571. https://doi.org/10.1016/j.jiec.2013.05. 015

Hazza, R., Hussein, M., 2015. Cationic Dye Removal By Sugarcane Bagasse Activated Carbon from Aqueous Solution. Glob. NEST J. 17, 784.

Hu, E., Shang, S., Tao, X., Jiang, S., Chiu, K., 2016. Regeneration and reuse of highly polluting textile dyeing effluents through catalytic ozonation with carbon aerogel catalysts. J. Clean. Prod. 137, 1055-1065. https://doi.org/10.1016/j.jclepro.2016. 07.194

Jain, R., Gupta, V.K., Sikarwar, S., 2010. Adsorption and desorption studies on hazardous dye Naphthol Yellow S S. J. Hazard. Mater. 182, 749-756. https://doi.org/10.1016/j.jhazmat.2010 .06 .098

Jamilatun, S., Setyawan, 2014. Pembuatan Arang Aktif Dari Tempurung Kelapa dan Aplikasinya Untuk Penjernihan Asap Cair. Spektrum Ind. 12, 73-86.

Lempang, M., 2014. Pembuatan dan Kegunaan Arang Aktif. Info Tek. EBONI 11, 65-80.

Miller, J.N., Miller, J.C., 2010. Statistics and chemometrics for analytical chemistry, 6. ed. ed. Prentice Hall, Harlow.

Misran, E., 2005. Industri Tebu Menuju Zero Waste Industry. J. Teknol. Proses 4, 6-10.

Natarajan, S., Bajaj, H.C., Tayade, R.J., 2018. Recent advances based on the synergetic effect of adsorption for removal of dyes from waste water using photocatalytic process. J. Environ. Sci. 65, 201-222. https://doi.org/10.1016/j.jes.2017.03.0 11

Ng, E.-P., Awala, H., Tan, K.-H., Adam, F., Retoux, R., Mintova, S., 2015. EMTtype zeolite nanocrystals synthesized from rice husk. Microporous Mesoporous Mater. 204, 204-209. https://doi.org/10.1016/j.micromeso.2 014.11.017

Pavia, D.L., Lampman, G.M., Kriz, G.S., 2001. Intorduction to Spectroscopy, 3rd ed. Thomson Learning, USA.

Piao, L., Liu, Q., Li, Y., Wang, C., 2009. Retracted article: The Adsorption of L-Phenylalanine on Oxidized SingleWalled Carbon Nanotubes. J. Nanosci. Nanotechnol. 9, 1394-1399. https://doi.org/10.1166/jnn.2009.C164

Pujiastuti, L., 2015. Diakui Dunia, Ekspor Batik RI Meningkat Setiap Tahun [WWW Document]. detikfinance. URL https://finance.detik.com/beritaekonomi-bisnis/d-3034083/diakuidunia-ekspor-batik-ri-meningkatsetiap-tahun (accessed 3.21.18).

Puspita, M., Firdaus, M.L., 2017. Pemanfaatan Arang Aktif Sabut Kelapa Sawit sebagai Adsoben Zat Warna Sintetis Reactive Red-120 dan Direct Green 26. J. Pendidik. Dan Ilmu Kim. 1, 7579.

Rios, R.R.A., Alves, D.E., Dalmázio, I., Bento, S.F.V., Donnici, C.L., Lago, R.M., 2003. Tailoring activated carbon by surface chemical modification with $\mathrm{O}, \mathrm{S}$, and $\mathrm{N}$ containing molecules. Mater. Res. 6, 129-135. https://doi.org/10.1590/S151614392003000200004

Rita, K., 2012. Adsorption of yellow dye: Acid yellow RR from its aqueous solution using two different samples of activated carbon by static batch method. Nat. Sci. 04, 112-115. https://doi.org/10.4236/ns.2012.42016

Sari, M.F.P., Loekitowati, P., Mohadi, R., Departemen Kimia, Fakultas Matematika dan Ilmu Pengetahuan Alam, Universitas Sriwijaya, Palembang 30128, 2017. Penggunaan Karbon Aktif dari Ampas Tebu 
Sebagai Adsorben Zat Warna Procion Merah Limbah Cair Industri Songket. J. Nat. Resour. Environ. Manag. 7, $37-40$. https://doi.org/10.19081/jpsl.2017.7.1. 37

Sasongko, D.P., Tresna, W.P., 2010. Identifikasi Unsur dan Kadar Logam Berat pada Limbah Pewarna Batik dengan Metode Analisis Pengaktifan Neutron 27, 6.

Simanjuntak, W., Sembiring, S., Manurung, P., Situmeang, R., Low, I.M., 2013. Characteristics of aluminosilicates prepared from rice husk silica and aluminum metal. Ceram. Int. 39, 9369-9375.

https://doi.org/10.1016/j.ceramint.201 3.04.112

Sudrajat, R., Pari, G., 2011. Arang Aktif Teknologi Pengolahan dan Masa Depannya. Badan Penelitian dan Pengembangan Kehutanan, Kementerian Kehutanan.

Tongpoothorn, W., Sriuttha, M., Homchan, P., Chanthai, S., Ruangviriyachai, C., 2011. Preparation of activated carbon derived from Jatropha curcas fruit shell by simple thermo-chemical activation and characterization of their physico-chemical properties. Chem. Eng. Res. Des. 89, 335-340. https://doi.org/10.1016/j.cherd.2010.0 6.012

Utomo, W.P., Nugraheni, Z.V., Rosyidah, A., Shafwah, O.M., Naashihah, L.K., Nurfitria, N., Ulfindrayani, I.F., 2018. Penurunan Kadar Surfaktan Anionik dan Fosfat dalam Air Limbah Laundry di Kawasan Keputih, Surabaya Menggunakan Karbon Aktif. Akta Kim. Indones. 3, 127-140.

Widihati, I.A.G., Suastuti, D.A., Nirmalasari, M.A.Y., 2012. Studi Kinetika Adsorpsi Larutan Ion Logam Kromium (Cr) Menggunakan Arang Batang Pisang (Musa paradisiaca) (Undergraduate Thesis). Universitas Udayana, Denpasar, Bali, Indonesia.

Yang, X., Zhang, Y., Wang, L., Cao, L., Li, K., Hursthouse, A., 2017. Preparation of a Thermally Modified Diatomite and a Removal Mechanism for 1Naphthol from Solution. Water 9, 651. https://doi.org/10.3390/w9090651

Zhu, Z., Zhang, M., Liu, F., Shuang, C., Zhu, C., Zhang, Y., Li, A., 2016. Effect of polymeric matrix on the adsorption of reactive dye by anion-exchange resins. J. Taiwan Inst. Chem. Eng. 62, 98103.

https://doi.org/10.1016/j.jtice.2016.01. 017 